\section{Association of the nematophagous fungi Arthrobotrys musiformis and Monacrosporium sinense in vitro and in vivo for biological control of equine cyathostomins}

\author{
Associação dos fungos nematófagos Arthrobotrys musiformis \\ e Monacrosporium sinense in vitro e in vivo para o controle \\ biológico de ciatostomíneos de equinos
}

\author{
Atílio Dalcin Júnior ${ }^{1}$ (D), Vinicius Monteiro Ferreira' ${ }^{1}$, Lorendane Millena de Carvalho* (i), \\ Felipe Boniedj Ventura Álvares ${ }^{3}$ (1) , Vinicius Longo Ribeiro Vilela ${ }^{4}$ (D) Carolina Magri Ferraz ${ }^{5}$ (D), \\ Francielle Bosi Rodrigues Veloso ${ }^{5}$ (D) , Thalita Fonseca Lima ${ }^{5}$ (D), Fabio Ribeiro Braga ${ }^{6}$ (D), \\ Jackson Victor de Araújo² (1) \\ 1 Veterinarian, Programa de Pós-Graduação em Medicina Veterinária (PPGMV), Departamento de Veterinária (DVT), \\ Universidade Federal de Viçosa (UFV). Campus Viçosa, MG, Brazil. \\ 2 Veterinarian, DSc., PPGMV, DVT, UFV, Campus Viçosa, MG, Brazil. \\ ${ }^{3}$ Undergraduate in Veterinary Medicine, Instituto Federal da Paraíba (IFPB), Souza PB, Brazil. \\ ${ }^{4}$ Veterinarian, DSc., IFPB, Souza, PB, Brazil. \\ ${ }^{5}$ Veterinarian, Programa de Pós-graduação em Ciência Animal (PPGCA), Universidade de Vila Velha (UVV), Vila Velha, ES, Brazil. \\ ${ }^{6}$ Veterinarian, DSc., Programa de Pós-graduação em Ciência Animal (PPGCA), Universidade de Vila Velha (UVV), Vila Velha, ES, Brazil.
}

\begin{abstract}
The fungi Arthrobotrys musiformis (A144 isolate) and Monacrosporium sinense (SF53 isolate) were evaluated for controlling L3 of cyathostomins. In vitro, Petri dishes containing 2\% water-agar were divided into groups: 1 (A144 + SF53); 2 (SF53); 3 (A144); 4 (control group). In vivo, 24 animals received pellets containing fungal mycelium. The animals were divided into four groups: 1 (100 g of pellets containing A144 + SF53 isolates); 2 (100 g of pellets containing A144 isolate); 3 (100 g of pellets containing SF53 isolate); 4 (Pellets without fungi). Feces were collected at 12, 24, 36, 48, 60 and 72 hours after pellet administration. The association of isolates, in vitro, was able to reduce L3 by $69.7 \%$, compared with the control group; A144 isolate reduced L3 by $77.3 \%$; and SF53 isolate reduced L3 by $84.3 \%$. In vivo, the association of fungi $A$. musiformis and $M$. sinense showed predatory activity against L3 of cyathostomins with efficacy ranged from $63.2 \%$ to $83 \%$. The association of the fungi $A$. musiformis and $M$. sinense both in vitro and in vivo proved to be efficient for controlling L3 of cyathostomins.
\end{abstract}

Keywords: worms, nematodes, horses.

\section{Resumo}

Os fungos Arthrobotrys musiformis (isolado A144) e Monacrosporium sinense (isolado SF53) foram avaliados no controle de L3 de ciatostomineos. In vitro, placas de Petri contendo ágar-água $2 \%$ foram divididas em grupos: 1 (A144 + SF53); 2 (SF53); 3 (A144); 4 (grupo controle). In vivo, 24 animais receberam péletes contendo micélio fúngico. Os animais foram divididos em quatro grupos: 1 (100 g de péletes contendo os isolados A144 + SF53); 2 (100 g de péletes contendo isolado A144); 3 (100 g de péletes contendo isolado SF53); 4 (péletes sem fungos). As fezes foram coletadas 12, 24, 36, 48, 60 e 72 horas após a administração dos péletes. A associação de isolados, in vitro, foi capaz de reduzir as L3 em 69,7\%, em comparação ao grupo controle. O isolado A144 reduziu as L3 em 77,3\% e o isolado SF53 reduziu em 84,3\%. In vivo, a associação dos fungos $A$. musiformis e $M$. sinense mostrou atividade predatória contra as L3 de ciatostomineos, com eficácia variando de 63,2\% a 83\%. A associação dos fungos A. musiformis e $M$. sinense in vitro e in vivo mostrou-se eficiente no controle de L3 de ciatostomineos.

Palavras-chave: parasitos, nematoides, equinos.

\section{BJ $\mathrm{M}$ \\ Brazilian Journal of Veterinary Medicine}

p-ISSN 0100-2430

How to cite: Dalcin Júnior, A., Ferreira, V. M. Carvalho, L. M., Álvares, F. B. V., Vilela, V. L. R. Ferraz, C. M., Veloso, F. B. R., Lima, T. F., Braga, F. R., \& Araújo, J. V. (2021). Association of the nematophagous fungi Arthrobotrys musiformis and Monacrosporium sinense in vitro and in vivo for biological control of equine cyathostomins. Brazilian Journal of Veterinary Medicine, 43 , e003021. https://doi.org/10.29374/2527-2179. bjvm003021

Received: July 15, 2021.

Accepted: September 10, 2021

\section{${ }^{*}$ Correspondence}

Lorendane Millena de Carvalho Laboratório de Parasitologia e Doenças Parasitárias, Departamento de Veterinária, Universidade Federal de Viçosa - UFV Av. P.H. Rolfs, $s / n$ CEP 36570-900 - Viçosa (MG), Brasil E-mail: lorendane@gmail.com
Copyright Dalcin Júnior et al. This is an Open Access article distributed under the terms of the Creative Commons Attribution Non-Commercial License, which permits unrestricted non-commercial use, distribution and reproduction in any medium provided the original work is properly cited. 


\section{Introduction}

The horse-rearing sector in Brazil had a turnover of around $\mathrm{R} \$ 16.5$ billion in 2018. The herd comprised more than 5 million head (IBGE, 2018) and influenced both the Brazilian and the global agribusiness sector. Thus, maintaining the health of the herd is a constant concern, with emphasis on gastrointestinal nematodiasis, which can cause serious health problems (Godéski et al., 2017).

In horses, two large groups of nematodes are known to be harmful to the health of these animals: large and small strongyles (the latter are also called cyathostomins) (Piccoli et al., 2015). These nematodes have a direct life cycle and can reinfect animals throughout the year. The most common parasite control strategy for horses has consisted of use of anthelmintics (Kaplan \& Nielsen, 2010, Nielsen et al., 2019; Peregrine et al., 2014). However, a worrying situation of parasite resistance to commonly used drugs has arisen (Braga et al., 2009). In this context, setting up a broad strategic plan for use of associative alternatives seems to be the most likely path towards attaining effective control (Tavela et al., 2012).

Nematophagous fungi are an example of success in reducing and controlling the free infectious forms (L3) of small and large equine strongyles that are present in pastures (Paz-Silva et al., 2011; Piccoli et al., 2015; Tavela et al., 2012). These organisms are present in Brazilian soil and perform predation by means of traps that capture the L3 forms of these strongyles (Castro et al., 2003; Costa et al., 2019).

However, it has become increasingly challenging to test associations of these fungi, given the discovery that they present synergistic activity in association with other fungi and/or in association with anti-helminthic drugs (Ferraz et al., 2020). Use of more than one biocontrol agent is considered to be one of the main suppressive measures that contribute towards controlling the presence of infectious agents in the soil (Ayupe et al., 2016).

The aim of the present study was to evaluate, in vitro and in vivo, the association between the fungi Monacrosporium sinense and Arthrobotrys musiformis as biological controller for equine cyathostomins.

\section{Material and methods}

\section{Fungi}

The nematophagous fungi M. sinense (SF53 isolate) and A. musiformis (A144 isolate) were obtained from the parasitology laboratory of Departamento de Veterinária, Universidade Federal de Viçosa, Brazil. The fungi were transferred to Petri dishes of $9 \mathrm{~cm}$ in diameter containing $2 \%$ water-agar medium (2\% WA) and were grown for seven days. To produce the mycelia, fragments of agar containing mycelium and spores of the fungus were transferred to a $250 \mathrm{~mL}$ Erlenmeyer flask, with $150 \mathrm{~mL}$ of GPY medium (glucose - soy peptone - yeast extract) and kept under agitation at a temperature of $26^{\circ} \mathrm{C}$, in the dark, for 15 days. After this period, the mycelial mass was recovered and dried for production of pellets in a sodium alginate matrix, in accordance with the technique described by Walker \& Connick Junior (1983) and modified by Lackey et al. (1993).

\section{Infective larvae of cyathostomins}

Feces were collected directly from the rectal ampoule of horses that were kept in the horserearing sector of UFV and were analyzed in the parasitology laboratory of the Departamento de Veterinária. The technique of counting eggs per gram of feces (EPG) was then carried out and, if the samples were found to be positive, coprocultures were made and the L3 were obtained using the Baermann technique (Ueno \& Gonçalves 1998). The EPG technique was conducted according to the following methodology: Dilution of $2 \mathrm{~g}$ of feces in $29 \mathrm{~mL}$ of saturated solution. Homogenization of the material, followed by filtration in sieve. Then, a mixture containing $14.5 \mathrm{~mL}$ of saturated solution and $14.5 \mathrm{~mL}$ of tap water was passed through the sieve. The material was homogenized with a pipette and aliquots were collected to fill the McMaster chamber. The L3 were identified using the dichotomous keys proposed by Madeira de Carvalho et al. $(2004,2008)$.

To quantify the larvae, 10 samples of $50 \mu \mathrm{L}$ of the suspension containing the larvae were counted under an optical microscope with a $4 \mathrm{x}$ objective lens (40x magnification), to establish 
the average number of larvae in the suspension volume. All of the larvae used in this experiment belonged to the cyathostomin group.

\section{Assay A (in vitro test)}

Sixty Petri dishes of diameter $9 \mathrm{~cm}$, each containing $20 \mathrm{~mL}$ of $2 \%$ water-agar (2\% WA), were used. These were divided into three treatments and one control, with 15 repetitions per group. In the treatments, two fragments of $4 \mathrm{~mm}$ of $2 \%$ WA containing the fungi that had been grown previously were added, as described by Ayupe et al. (2016). In group 1, each Petri dish received one fragment with the A144 isolate (A. musiformis) and one fragment with the SF53 isolate ( $M$. sinense); in group 2, each dish received two fragments with A144 (A. musiformis); in group 3, each dish received two fragments with SF53 ( $M$. sinense); and group 4 served as a control group, so there was no addition of fragments containing fungi to the dishes. The 60 dishes were kept in the dark in an environmental chamber, at $26^{\circ} \mathrm{C}$ for 10 days, for fungal growth.

To evaluate the in vitro predatory efficacy of the isolates in association and/or separately, after the fungal growth in the dishes, 1000 L3 were added to each dish and were kept in an environmental chamber for 7 days. Daily observations were made and, at the end of this period, the larvae in each dish were recovered using the Baermann technique (Ueno \& Gonçalves, 1998).

\section{Assay B (in vivo test)}

For the fungal viability test, 24 adult female horses of the Mangalarga Marchador breed, aged between four and eight years, were used. The animals were weighed and divided into four groups of six animals each. Fourteen days before started experimental assay with fungi, the animals were treated with an anthelmintic formulation containing two active ingredients ( $0.4 \%$ ivermectin and 38.3\% pyrantel pamoate) (Centurion ${ }^{\circledast}$, Vallée S/A), using the dose established by the manufacturer.

The animals received pellets in a sodium alginate matrix orally, with the following descriptions: group 1 (100 g of pellets containing the A144 + SF53 isolates); group 2 (100 g of pellets containing the A144 isolate); group 3 (100 g of pellets containing the SF53 isolate); and group 4 (control, containing pellets without fungi). The pellets were supplied individually to the animals and feces were collected at 12, 24, 36, 48, 60 and 72 hours after pellet supply. At each of these times, approximately $100 \mathrm{~g}$ of feces were collected from each animal, directly from the rectal ampoule, as described by Araújo et al. (2010). From each sample, $4 \mathrm{~g}$ of feces were used. The feces were spread, with the aid of a steel spatula, in Petri dishes containing $2 \%$ WA. Then, each dish received $1000 \mathrm{~L} 3$ of cyathostomins. The dishes of the treated and control groups were kept in the dark in an environmental chamber, at $26^{\circ} \mathrm{C}$ for 15 days. At the end of this period, the Baermann technique was performed, to recover any larvae that had not been predated by the fungi.

\section{Statistical analysis}

The percentage of larval reduction in tests A and B, in relation to the control, was calculated using the following formula:

\footnotetext{
Reduction $(\%)=[($ Mean $L 3$ recovered from CG - Mean $L 3$ recovered from $T G) /$ Mean $L 3$ recovered from CG $] \times 100$

CG = Control group; $\mathrm{TG}=$ Treated group.

The data were submitted to analysis of variance (ANOVA, F test). Subsequently, the averages were compared using the Tukey`s test at the level of 5\% probability using the software Biostat 5.0 (Ayres et al., 2007).
}

\section{Results}

The in vitro test showed that all the fungal treatments presented predatory efficacy, in comparison with the control group $(\mathrm{p} \leq 0.05)$. The highest percentage of larval reduction occurred in group 3 ( $M$. sinense), with a reduction of $84.3 \%$, such that the average number of larvae recovered was 47.6 \pm 6.9. Group 2 (A. musiformis) was the second most effective in terms of predatory activity, with larval reduction of $77.3 \%$ and a mean number of larvae recovered of $69.1 \pm 7.1$. In group 1 
(A. musiformis and $M$. sinense), there was a reduction of $69.7 \%$, with an average number of larvae recovered of 92.1 \pm 7.6. In group 4 (control), the average number of larvae recovered was 304.1 \pm 18.2 .

In the in vivo test, the daily observations of the Petri dishes showed that there was fungal growth in all treatments, with the formation of traps and conidia characteristic of the isolates used. Predatory activity against infective larvae was observed, thus proving that viable fungi had germinated. The fungi $A$. musiformis and $M$. sinense, in association or separately, showed predatory activity at all collection times (12,24,36,48,60 and 72 hours) ( $\mathrm{p} \leq 0.05)$ (Table1). Group 1 showed the greatest larval predation ( $\mathrm{p} \leq 0.05$ ) at all times, followed by groups 3 and 2 , respectively. All the treated groups had a higher level of predation at $60 \mathrm{~h}$, with an efficiency of $83 \%$ in group 1 , $66.1 \%$ in group 2 and $69.7 \%$ in group 3.

Table 1. Means and standard deviations and percentages of reduction of cyathostomins infective larvae (L3) by the fungi Arthrobotrys musiformis (A144 isolate) and Monacrosporium sinense (SF53 isolate) after passing in sodium alginate matrix pellets through the gastrointestinal tract of horses, and recovered in the feces at times 12, 24, 36 48, 60 and 72 hours after administration of pellets. Experimental groups: Group 1 (100g pellets containing the fungi A144 + SF53); Group 2 (100g pellets containing only the fungus A144); Group 3 (100g pellets containing only the fungus SF53) and group 4 (control, containing pellets without fungi). Results obtained after 15 days of incubation of animal feces with $1000 \mathrm{~L} 3$ of cyathostomins, in Petri dishes.

\begin{tabular}{|c|c|c|c|c|c|c|c|}
\hline \multirow{2}{*}{$\begin{array}{c}\text { Time } \\
\text { (h) }\end{array}$} & \multicolumn{2}{|c|}{ Group 1} & \multicolumn{2}{|c|}{ Group 2} & \multicolumn{2}{|c|}{ Group 3} & \multirow{2}{*}{$\begin{array}{c}\text { Control } \\
\text { L3 Recovered }\end{array}$} \\
\hline & L3 Recovered & $\begin{array}{c}\text { Reduction of } \\
\text { L3 (\%) }\end{array}$ & L3 Recovered & $\begin{array}{c}\text { Reduction of } \\
\text { L3 (\%) }\end{array}$ & L3 Recovered & $\begin{array}{c}\text { Reduction of } \\
\text { L3 (\%) }\end{array}$ & \\
\hline 12 & $83.3^{c}(6.4)$ & 74.5 & $112.6^{\text {bc }}(6.8)$ & 65.4 & $112.0^{\mathrm{b}}(7.3)$ & 65.7 & $326.1^{\mathrm{a}}(13.2)$ \\
\hline 24 & $67.6^{c}(6.6)$ & 76.8 & $103.1^{\mathrm{b}}(6.4)$ & 64.6 & $103.6^{\mathrm{b}}(7.1)$ & 64.4 & $291.3^{a}(11.3)$ \\
\hline 36 & $127.7^{\mathrm{c}}(8.7)$ & 63.2 & $136.2^{\mathrm{c}}(6.8)$ & 60.7 & $199.6^{\mathrm{b}}(9.3)$ & 42.4 & $346.6^{a}(13.4)$ \\
\hline 48 & $90.6^{c}(6.5)$ & 67.3 & $97.2^{c}(6.3)$ & 64.9 & $148.3^{\mathrm{b}}(7.9)$ & 46.4 & $276.9^{\mathrm{a}}(15.1)$ \\
\hline 60 & $44.8^{\complement}(6.9)$ & 83.0 & $89.6^{\mathrm{b}}(7.3)$ & 66.1 & $79.9^{\mathrm{b}}(6.5)$ & 69.7 & $264.0^{\mathrm{a}}(13.0)$ \\
\hline 72 & $66.3^{c}(6.3)$ & 71.3 & $95.5^{\mathrm{b}}(7.2)$ & 58.6 & $84.9^{\mathrm{b}}(7.0)$ & 63.2 & $240.8^{a}(17.5)$ \\
\hline
\end{tabular}

Different letters on the same line differ statistically from each other by Tukey's test at $5 \%$ significance.

\section{Discussion}

Few studies have been carried out to evaluate the predatory activity of associations of nematophagous fungi (Tavela et al., 2012). The great difficulty in making evaluations of this nature lies in inclusion of mycelial masses belonging to two or more fungal isolates, in vehicles that pass through the gastrointestinal tract. In addition, because of the mechanism of fungistasis, the results may be antagonistic for fungal activity (Dalio, 2013).

No toxic metabolites are known to be produced by A. musiformis (A144) and M. sinense(SF53). Moreover, in the present study, no phenomenon of inhibition of fungal germination was noticed, either in assay A or in assay B. Following the methodology of Ayupe et al. (2016), absence of zones of fungal inhibition was verified in the Petri dishes of test A. Both of the isolates tested showed normal growth, with an average reduction in the numbers of L3 of the cyathostomins of $69.7 \%$. In test B, at the end of the experimental period (72 hours), the association of A144 + SF53 caused a reduction in $\mathrm{L} 3$ of $71.3 \%$, followed by 58.6\% for A144 alone and 63.2\% for SF53 alone.

The results described above were in agreement with the findings of Dalla Pria \& Ferraz (1996), who mentioned that use of nematophagous fungi in combination can minimize possible failures in their administration or even enhance their actions as biocontrol agents. The present study provides the first report of the combined predatory activity of the fungi A. musiformis (A144) and M. sinense (SF53) on L3 of cyathostomins, which may form an integrated parasite control strategy of potential interest. The average numbers of $\mathrm{L} 3$ that were recovered after the treatments of the present study, especially in the group treated with the fungi used in association in the in vivo test, showed that high percentages of larval reduction were achieved.

Use of nematophagous fungi constitutes a biological means for controlling L3 that are present in the environment (Tavela et al., 2012). To use these agents in the field, there needs to be a 
way to protect them from the adverse conditions that they face during passage through the gastrointestinal tract, so that they become dispersed in the pasture environments where horses are reared and can develop their hyphae and resistance structures during growth in nutrient-rich fecal pats. One way to do this is through using pellets in a sodium alginate matrix, which has been shown to be a good alternative for oral administration of nematophagous fungi (Assis et al., 2012; Braga et al., 2009; Rodrigues et al., 2020; Tavela et al., 2013).

The pelleted formulation in sodium alginate is prepared using inert materials and is easily administered to animals. The pellets pass through the animals' gastrointestinal tract and are released via the feces. The fungi contained in these pellets? colonize the fecal pats and can then prey on the L3 (Braga et al., 2009). Satisfactory results have been achieved with this formulation under both laboratory and field conditions. Fungi stored in pellets have been seen to remain viable for up to 60 months at $2-8{ }^{\circ} \mathrm{C}$ (Costa et al., 2019).

During the in vivo test, all groups reached their highest levels of larval predation at $60 \mathrm{~h}$ after administration of the treatment (G1 - 83.0\%; G2 - 69.1\%; G3 - 69.7\%). The predation rate varies according to the rate of fungal release in the feces and it is common for these formulations in sodium alginate to have their peak of predatory action at $60 \mathrm{~h}$ after oral administration (Costa et al., 2019; Rodrigues et al., 2020).

The results from the present study demonstrate the potential of using these fungi either in association or separately, on the L3 of cyathostomins. In comparison, Braga et al. (2009) also demonstrated, in an in vitro assay, reductions in the L3 of cyathostomins of $85 \%$ and $72.5 \%$, using the fungi Arthrobotrys robusta (I31 isolate) and Monacrosporium thaumasium (NF34 isolate), respectively. However, these authors only used these isolates separately. In a study carried out by Castro et al. (2003) on different fungi at temperatures between 25 and $30{ }^{\circ} \mathrm{C}$, percentage reductions in cyathostomin larvae of between $58.45 \%$ and $89.4 \%$ were observed for A. musiformis. In comparison with the results from the present study, it is worth noting that these differences may be related not only to temperature variation, but also to the fungal isolate used.

\section{Conclusion}

The use of an association of the fungi $A$. musiformis and $M$. sinense, both in vitro and in vivo, proved to be efficient for controlling the infective larvae of cyathostomins and could be a tool for the control of these nematodes in the environment.

\section{Acknowledgements}

To Coordenação de Aperfeiçoamento de Pessoal de Nivel Superior (CAPES), Fundação de Amparo à Pesquisa de Minas Gerais (FAPEMIG) and Conselho Nacional de Desenvolvimento Científico e Tecnológico (CNPq) for financial support.

\section{Ethics statement}

The experiments were carried out after approval by the "Council of Ethics for Use of Production Animals" of the Universidade Federal de Viçosa (CEUAP), protocol number 124/2018.

\section{Financial support}

ADJ - received scholarship from CAPES (Coordenação de Aperfeiçoamento de Pessoal de Nível Superior); VMF - received scholarship from CAPES (Coordenação de Aperfeiçoamento de Pessoal de Nivel Superior); LMC - received scholarship from CAPES (Coordenação de Aperfeiçoamento de Pessoal de Nível Superior); FBVA - received scholarship from CNPq (Conselho Nacional de Desenvolvimento Científico e Tecnológico); JVA - Acquisition of the financial support for the project leading to this publication (FAPEMIG, CAPES and CNPq).

\section{Conflict of interests}

ADJ, VMF, LMC, FBVA, VLRV, CMF, FBRV, TFL, FRB and JVA - No conflict of interest. 


\section{Authors' contributions}

ADJ, VMF and LMC - Development of methodology; preparation and writing the initial draft. ADJ, LMC, FRB and JVA - Application of statistical study data, Review and Editing manuscript. ADJ, LMC, FBVA, VLRV, CMF, FBRV, TFL, FRB and JVA - Writing, Review and Editing manuscript. JVA - Acquisition of the financial support for the project leading to this publication

\section{Availability of complementary results}

The authors must identify where readers can access any complementary information available, such as in an online repository or from the authors on request. We suggest consulting https:// wp.scielo.org/wp-content/uploads/Lista-de-Repositorios-Recomendados_pt.pdf

The study was carried out at Laboratório de Parasitologia Veterinária e Doenças Parasitárias, Departamento de Medicina Veterinária, Universidade Federal de Viçosa-UFV, Viçosa, MG, Brasil.

\section{References}

Araujo, J.M., Araújo, J.V., Braga, F.R., Carvalho, R.O. (2010). In vitro predatory activity of nematophagous fungi and after passing through gastrointestinal tract of equine on infective larvae of Strongyloides westeri. Parasitology Research, 107,103-107. https://doi.org/10.1007/s00436-010-1841-y.

Assis, R. C. L., Luns, F. D., Araújo, J. V., \& Braga, F. R. (2012). Biological control of trichostrongyles in beef cattle by the nematophagous fungus Duddingtonia flagrans in tropical southeastern Brazil. Experimental Parasitology, 132(3), 373-377. http://dx.doi.org/10.1016/j.exppara.2012.08.013. PMid:22975475.

Ayres, M., Ayres, J. R. M., Ayres, D. L., \& Santos, A. S. (2007). Aplicações estatísticas nas áreas de ciências biológicas. Brasília: CNPq.

Ayupe, T. H., Monteiro, T. S. A., Braga, F. R., Soares, F. E. F., Mello, I. K., \& Araújo, J. V. (2016). Assessment of compatibility between the nematophagous fungi Artbrobotrys robusta and Duddingtonia flagrans under laboratory conditions. Revista Iberoamericana de Micologia, 33(2), 129-130. http://dx.doi.org/10.1016/j. riam.2015.07.001. PMid:26631950.

Braga, F. R., Araújo, J. V., Carvalho, R. O., Araújo, J. M., Silva, A. R., \& Campos, A. K. (2009). Controle in vitro de larvas infectantes de ciatostomíneos (NEMATODA: CYATHOSTOMINAE) de equinos utilizando os fungos predadores Duddingtonia flagrans, Monacrosporium thaumasium e Arthrobotrys robusta. Ciência Animal Brasileira, 10(3), 887-892. https://www.revistas.ufg.br/vet/article/view/2720

Castro, A. A., Oliveira, C. R. C., Anjos, D. H. S., De Ornelas, E. I., Bittencourt, V. R. E. P., Araújo, J. V., Sampaio, I. B. M., \& Rodrigues, M. L. A. (2003). Potencial dos fungos nematófagos Arthrobotrys sp. e Monacrosporium thaumasium para o controle de larvas de ciatostomíneos de equinos (Nematoda: Cyathostominae). Revista Brasileira de Parasitologia Veterinária, 12(2), 53-57.

Costa, P. W. L., Alvares, F. B. V., Bezerra, R. A., Sarmento, W. F., Silva, F. F., Rodrigues, J. A., Ferreira Feitosa, T., Araújo, J. V., Braga, F. R., \& Vilela, V. L. R. (2019). Effect of refrigeration storage of nematophagous fungi embedded in sodium alginate pellets on predatory activity against asinine gastrointestinal nematodes. Biocontrol Science and Technology, 19(11), 1106-1117. http://dx.doi.org/10.1080/09583157.2019.1658180.

Dalio, R.J., Fleischmann, F., Humez, M., Osswald, W. (2014). Phosphite protects Fagus sylvatica seedlings towards Phytophthora plurivora via local toxicity, priming and facilitation of pathogen recognition. Plos One, 9(1): e87860. https://doi.org/10.1371/journal.pone.0087860.

Dalla Pria, M., \& Ferraz, S. (1996). Controle biológico de Meloidogyne incognita, raça 3, por seis espécies de Monacrosporium, isoladas ou combinadas com Verticillium chlamydosporium. Fitopatologia Brasileira, 21, 30-34.

Ferraz, C. M., Silva, L. P. C., Soares, F. E. F., Souza, R. L. O., Tobias, F. L., Araújo, J. V., Veloso, F. B. R., Laviola, F. P., Endringer, D. C., de Gives, P. M., \& Braga, F. R. (2020). Effect of silver nanoparticles (AgNP's) from Duddingtonia flagrans on cyathostomins larvae (subfamily: Cyathostominae). Journal of Invertebrate Pathology, 174, 107395. http://dx.doi.org/10.1016/j.jip.2020.107395. PMid:32433916.

Godéski, A., Pedrassani, D., Szczerbowski, C.R. (2017). Eficácia de anti-helmínticos em equinos da raça Crioula no município de Major Vieira/SC. Revista Acadêmica Ciência Animal, 15, 59-66. https://doi.org/10.7213/ academica.15.2017.08.

Instituto Brasileiro de Geografia e Estatística - IBGE. (2018). Produção da pecuária municipal. https://biblioteca. ibge.gov.br/visualizacao/periodicos/84/ppm_2018_v46_br_informativo.pdf

Kaplan, R. M., \& Nielsen, M. K. (2010). An evidence-based approach to equine parasite control: It ain't the 60s anymore. Equine Veterinary Education, 22(6), 306-316. http://dx.doi.org/10.1111/j.2042-3292.2010.00084.x.

Lackey, B. A., Muldoon, A. E., \& Jaffee, B. A. (1993). Alginate pellet formulation of Hirsutella rossiliensis for biological control of plant-parasitic nematodes. Biological Control,3(2), 155-160. http://dx.doi.org/10.1006/bcon.1993.1023.

Madeira de Carvalho, L. M., Fazendeiro, M. I., \& Afonso-Roque, M. M. (2004). Estudo morfométrico das larvas infectantes (L3) dos estrongilídeos (Nematoda: Strongylidae) dos equídeos - 1. Género Cyathostomum s.l. Acta Parasitológica Portuguesa, 11(1-2), 23-32. 
Madeira de Carvalho, L. M., Fazendeiro, M. I., \& Afonso-Roque, M. M. (2008). Estudo morfométrico das larvas infectantes (L3) dos estrongilídeos (Nematoda: Strongylidae) dos equídeos. 4. Estudo das populações de equídeos bravios e domésticos através do método de análise dos morfotipos de L3 de Cyathostomum sensu latum. Acta Parasitológica Portuguesa, 15(1-2), 65-70.

Nielsen, M. K., Mittel, L., Grice, A., Erskine, M., Graves, E., Vaala, W., Tully, R. C., French, D. D., Bowman, R., \& Kaplan, R. M. (2019). AAEP parasite control guidelines, american association of equine practitioner. https://aaep.org/ sites/default/files/Guidelines/AAEPParasiteControlGuidelines_O.pdf

Paz-Silva, A., Francisco, I., Valero-Coss, R. O., Cortinasa, F. J., Sánchez, J. A., Francisco, R., Arias, M., Suárez, J. L., López-Arellano, M. E., Sánchez-Andrade, R., \& Mendoza de Gives, P. (2011). Ability of the fungus Duddingtonia flagrans to adapt to the cyathostomin egg-output by spreading chlamydospores. Veterinary Parasitology. 79(1-3), 277-282. http://dx.doi.org/10.1016/j.vetpar.2011.02.014. PMid:21402449.

Peregrine, A., Molento, M. B., Kaplan, R. M., \& Nielsen, M. K. (2014). Anthelmintic resistance in important parasites of horses: Does it really matter? Veterinary Parasitology, 201(1-2), 1-8. http://dx.doi.org/10.1016/j. vetpar.2014.01.004. PMid:24485565.

Piccoli, C., Marques, S. M. T., Appel, G., Da Silveira, E., Siqueira, G. B., Loos, D. E., \& Mattos, M. J. T. (2015). Helmintos intestinais em cavalos de trabalho e de lazer de Porto Alegre/RS. Science and Animal Health, 3(1), 56-64. http:// dx.doi.org/10.15210/sah.v3i1.4227.

Rodrigues, J. Á., Alvares, F. B. V., Silva, J. T., Ferreira, L. C., Lopes da Costa, P. W., Sarmento, W. F., Ferreira Feitosa, T., Araújo, J. V., Braga, F. R., \& Longo Ribeiro Vilela, V. (2020). Predatory effects of the fungus Arthrobotrys cladodes on sheep gastrointestinal nematodes. Biological Science and Technology, 30(8), 830-839. http://dx.doi. org/10.1080/09583157.2020.1775176.

Tavela, A. O., Araújo, J. V., Braga, F. R., Araujo, J. M., Magalhães, L. Q., Silveira, W. F., \& Borges, L. A. (2012). In vitro association of nematophagous fungi Duddingtonia flagrans (ACOO1), Monacrosporium thaumasium (NF34) and Pochonia chlamydosporia (VC1) to control horse cyathostomin (Nematoda: Strongylidae). Biocontrol Science and Technology, 22(5), 607-610. http://dx.doi.org/10.1080/09583157.2012.672952.

Tavela, A. O., Araújo, J. V., Braga, F. R., Silveira, W. F., Dornelas e Silva, V. H., Carretta Júnior, M., Borges, L. A., Araujo, J. M., Benjamin, L. A., Carvalho, G. R., \& Paula, A. T. (2013). Coadministration of sodium alginate pellets containing the fungi Duddingtonia flagrans and Monacrosporium thaumasium on cyathostomin infective larvae after passing through the gastrointestinal tract of horses. Research in Veterinary Science, 94(3), 568572. http://dx.doi.org/10.1016/j.rvsc.2012.11.011. PMid:23274060.

Ueno, H., \& Gonçalves, P. C. (1998). Manual para diagnóstico das helmintoses de ruminantes (4. ed.). Tokyo: JICA.

Walker, H. L., \& Connick Junior, W. J. (1983). Sodium alginate for production and formulation of mycoherbicides. Weed Science, 31(3), 333-338. http://dx.doi.org/10.1017/s0043174500069113. 